\title{
THE
}

5-16-2011

\section{Is There a Future for Library Catalogers}

Michael A. Cerbo II

University of Rhode Island, mcerbo@uri.edu

Follow this and additional works at: https://digitalcommons.uri.edu/lib_ts_pubs

Part of the Library and Information Science Commons

\section{Citation/Publisher Attribution}

Cerbo, Michael A.. "Is There a Future for Library Catalogers." , (2011). doi: 10.1080/ 01639374.2011.571504.

This Article is brought to you for free and open access by the Technical Services at DigitalCommons@URI. It has been accepted for inclusion in Technical Services Department Faculty Publications by an authorized administrator of DigitalCommons@URI. For more information, please contact digitalcommons-group@uri.edu. 


\title{
Is There a Future for Library Catalogers?
}

\author{
Michael A. Cerbo II \\ University of Rhode Island
}

There has been a great multitude of material written on the future of cataloging. For the past thirty years this debate has increased with the continued growth of online resources and greater access to the World Wide Web. Do library administrators believe budgetary resources would be better spent on other matters? Would the patron be left with an overabundance of electronic information to muddle through on their own, or rely on computer experts, rather than the library catalog and librarians? In fact, is there even a need for a library catalog? "Today, a large and growing number of students and scholars routinely bypass library catalogs in favor of other discovery tools, and the library catalog represents a shrinking proportion of the universe of scholarly information." ${ }^{1}$ Others see the role of catalogers changing to meet these new demands. One report from the University of California Libraries states "If we wish to remain a contender in the information marketplace, we need to incorporate efficient ways for obtaining, creating and exporting metadata. We must respond to demands to enrich our data in new ways, to add value and provide unique services to our users, without draining our budget."

As technology continues to change and information is gathered from a plethora of sources that once were unimaginable, librarians continue to adapt so as to meet the needs of those researchers, students, teachers and the general public. In so doing, the librarians knowledge and workload is consistently shifting to keep up with the latest information technology, including databases, electronic resources, repositories, web searches, online catalogs, e-books, and more. The debate over the need for catalogers, cataloging principles and set rules in this new "Google age" of key word searching and web browsing brings forth the real 
question of the necessity of cataloging. Is there a need for library catalogers that there once was? One report from the Library of Congress states that "...the future of library control 'will be collaborative, decentralized, international in scope, and Web-based.",3 Others see the need for cataloging more today than ever. Michael Gorman, past president of the American Library Association sees the digital age as a great opportunity for catalogers, with the library of the future having an "...integrated catalog into all aspects of its programs and services."4

The more literature one studies on this topic the more one can see a dramatic change in the profession. Academic institutions are using the skills of cataloging professionals to develop online "digital repositories" which can house any type of information from professional writings, historical documents and thesis, to art productions, online journals and biographical information. Utilizing cataloging expertise and experience in establishing the proper metadata to populate any digital repository is vital in enabling more efficient use of the data by researchers. A study conducted by Indiana University stated, "Much hope is placed on the ability of an institutional repository to rescue scholarly communication, yet in no way can it become part of this conceptual global system unless there is a strong backbone of cataloging and metadata." (emphasis added) In addressing metadata quality in digital repositories, JungRan Park states "Bearing on the complexity of natural language, Heflin and Hendler stress the indispensability of cataloging professionals and human indexers in the metadata creation process: 'it is difficult for machines to make determinations of this nature, even if they have access to a complete automated dictionary and thesaurus.,"6 All of a university's theses, faculty publications, student projects, institution research, gray literature and more can be placed online for users to access, but if that information is not easily retrievable, the benefit of having all of that information together is lost. 
Some cataloging librarians see these changes as making their work more valuable, not less. Betsy Simpson writes "The role of catalogers within academic libraries is evolving to meet new demands and cultivating a broader understanding of cataloging - one that focuses on collections, not the catalog, and applies cataloger expertise across metadata activities. Working

collaboratively as never before, catalogers are reinventing their place within the library." ${ }^{, 7}$ As the materials in most libraries change from fewer traditional paper books and periodicals to more digital and electronic formats, catalogers and cataloging continue to change as well, learning to work in broader digital environments such as digital repositories.

In adapting to this digital tsunami of new materials, it appears that the cataloging community is likely to adopt a new set of rules to replace the Anglo American Cataloguing Rules 2nd Ed. (AACR2). Known as RDA (Resource Description and Access), these new cataloging standards are designed to improve flexibility in rules for dealing with the changing landscape of resource description and access. With the ever increasing use of electronic resources, catalogers are given the opportunity of supplying the user with accurate and usable records to ensure that the materials that are sought are actually found. It is no longer just books and magazines, but electronic journals, websites and repositories that are rapidly increasing the amount of resources and the methods used in collecting them. Researchers are no longer restricted to a card catalog or even the resources of one particular library. The entire web and all that it entails are available at the push of a button or the click of the mouse. The massive amount of data can be an overwhelming prospect for the researcher who needs factual, well researched information, and not a whimsical opinion placed on someone's blog. RDA incorporates and updates AACR2 and applies the new FRBRized concept applications allowing the cataloger to be better equipped in organizing the vast resources of information available and utilizing the standardized descriptive 
access tools in guiding researchers to materials that might otherwise not have been found. ${ }^{8}$ As Copeland states "...RDA is a content standard intended for the digital age." ${ }^{9}$ RDA is seen as an additional tool to aid the cataloger in supplying the right information in the right format to the researchers or patrons who deem the information of value. In this quest to aid in the searching of information, the cataloger also provides subject analysis, controlled vocabulary and classification information to the metadata, enhancing access to a multitude of digital and non-digital resources.

This new approach of RDA and updates to other cataloging standards comes during lean budgetary times. The library cataloger of today is the one that is often seen as expendable. Technology personnel, non-professional catalogers or general staff are commonly used as suitable replacements for the overpriced catalog librarian. As one library director states "Cataloguing (sic) is perceived by many who hold the budgetary controls in our libraries as a resource waster in many ways." 10 Others disagree and prove the catalogers worth by what the cataloger actually does: "No library director in his or her right mind would dare tell the dean or the college president that, 'henceforth, the university will be providing a lower quality of service for all its patrons and proud of it.' But that is exactly what they are saying when speaking of lean records, less bibliographic data, less authority control..."11

Many academic libraries are redefining the role of catalogers for themselves, trying to fill other needs at the same time. Digital Initiative Librarian, E-resource Librarian, Library Information Technologist, and Metadata Librarian have all been advertised by colleges and universities across the country. All include requirements involving some standard cataloging functions of a professional cataloger along with new responsibilities such as electronic resources maintenance, creating and maintaining digital repositories, teaching and management responsibilities. This “real world” observation substantiates Sally Glasser's comments “To meet 
the challenges of today's catalog positions, library students must develop a broader set of skills that, in addition to the traditional theory and practice of principles of bibliographic control and metadata standards, include management skills, computer skills, the ability to work in a team, flexibility, and, perhaps most important of all, a willingness and ability to learn and embrace continuous change." 12 In Glasser's comments one could see the "old" cataloging position as no longer necessary and a professional shift to a more general-technical occupation. Yet the authors Park and Lu show that $65.4 \%$ of these new positions are looking for "general cataloging" as well. This was described as “...activities such as descriptive and subject cataloging and authority control...This indicates that traditional cataloging tasks and practices are still highly relevant and are being integrated with the activities of metadata creation and electronic resource management that characterize the key roles that metadata professionals play in the digital environment."13 This shows that cataloging knowledge must be integrated into job descriptions for current and future development and maintenance of digital data.

It remains clear that the future of cataloging appears to be in flux, with much work to be done and less and less resources to do that work. One goal of RDA is to help the understaffed, overworked cataloger meet the new demands of a digital age. When library administrators deal with personnel shortages in almost every department - it seems less likely that a cataloging position will be filled. RDA might help to streamline the cataloging process, allowing the cataloger to work more efficiently on large quantities of data and focus less on the craft of individual record building. Could it be that what Osborn wrote in 1941 might begin to happen early in the $21^{\text {st }}$ Century, "Cataloging does not need to call for so much craftsmanship. In point of fact, the less a cataloger is a craftsman pure and simple, the more room there is for him to be 
just an excellent librarian." ${ }^{\prime 14}$ An excellent librarian - this is what catalogers are and will continue to be in the future.

The need for catalogers is growing, now more than ever, but will there be librarians that are willing to take on this rewarding task? It is evident that the abilities of the modern cataloger are necessary in this environment of rapidly growing collections of information. Whether library administrators will take advantage of the skills catalogers provide to enhance the efficiency and effectiveness of metadata access is a crucial question. The current "information age" is useless if those that need the information are not able to retrieve it. Catalogers are the link in the chain that helps get the information where it needs to be.

${ }^{1}$ Calhoun, Karen. "Changing nature of the catalog and its integration with other discovery tools," (Ithaca: NY, Cornell University Library, 2006), 5.

${ }^{2}$ University of California. Bibliographical Service Task Force, "Rethinking how we provide bibliographic service for the University of California," (2005, December). Los Angeles: CA, University of California, Dec. 2005), 9.

${ }^{3}$ Foster, Andrea L., and Jennifer Howard. "Library of Congress Report Urges Technological Updates of Cataloging Strategies." Chronicle of Higher Education 54, no. 21 (February 2008): A11. Academic Search Premier, EBSCOhost (accessed November 17, 2010).

${ }^{4}$ Gorman, Michael. "The corruption of cataloging." Library Journal 120, no. 15 (September 15, 1995): 32. Academic Search Premier, EBSCOhost (accessed June 7, 2008).

${ }^{5}$ Byrd, J., et. al. "White paper on the future of cataloging at Indiana University." (Bloomington: IN: Indiana University, Jan. 2006), 5.

${ }^{6}$ Park, Jung-Ran. "Metadata Quality in Digital Repositories: A Survey of the Current State of the Art." Cataloging \& Classification Quarterly 47, no. 3/4 (May 2009): 213-228. Library, Information Science \& Technology Abstracts with Full Text, EBSCOhost (accessed March 2, 2011)

${ }^{7}$ Simpson, Betsy. "Collection Define Cataloging's Future." Journal of Academic Librarianship 33, no. 4 (July 2007): 507-511. Academic Search Premier, EBSCOhost (accessed June 8, 2008)

${ }^{8}$ IFLA Study Group on the Functional Requirements for Bibliographic Records. "Functional Requirements for Bibliographical Records: Final report." (February 2009) Accessed March 2. 2011 at http://www.ifla.org/files/cataloguing/frbr/frbr_2008.pdf

${ }^{9}$ Copeland, Jud H. "RDA and FRBR: A Brave New World in Cataloging A guide to understanding the fundamental changes in cataloging." Arkansas Libraries 67, no. 2 (Summer 2010): 14-19. Library, Information Science \& Technology Abstracts with Full Text, EBSCOhost (accessed November 16, 2010).

${ }^{10}$ Warren, Jenny. "Directors' Views of the Future of Cataloguing in Australia and New Zealand: a Survey." Australian Academic \& Research Libraries 38, no. 4 (December 2007): 239-251. Academic Search Premier, EBSCOhost (accessed June 7, 2008)

${ }^{11}$ Harmon, Joseph C. "The Death of Quality Cataloging: Does It Make a Difference for Library Users?" Journal of Academic Librarianship 22, no. 4 (July 1996): 306. Academic Search Premier, EBSCOhost (accessed June 6, 2008). 
${ }^{12}$ Glasser, Sally. "The Changing Face of Cataloging Positions at Academic Institutions: What Skill Set is Needed, and How Can Students Prepare?" Serials Librarian 51, no. 3/4 (February 2007): 39-49. Academic Search Premier, EBSCOhost (accessed June 6, 2008).

${ }^{13}$ Park, Jung-ran, and Caimei Lu. "Metadata Professionals: Roles and Competencies as Reflected in Job Announcements, 2003-2006." Cataloging \& Classification Quarterly 47, no. 2 (April 2009): 145-160. Library, Information Science \& Technology Abstracts with Full Text, EBSCOhost (accessed November 16, 2010).

${ }^{14}$ Osborn, A. “The Crisis in Cataloging.” The Library Quarterly, 11, no.4 (October 1941): 393-411. JSTOR (accessed November 16, 2010). 